\title{
Diversity and characteristics of mangrove vegetation in Pulau Rimau Protection Forest, Banyuasin District, South Sumatra, Indonesia
}

\author{
ERNIK YULIANA ${ }^{1, \vartheta}$, YUNI TRI HEWINDATI ${ }^{1}$, ADI WINATA ${ }^{1}$, WIBOWO A. DJATMIKO ${ }^{2}$, ATI RAHADIATI ${ }^{3}$ \\ ${ }^{1}$ Department of Biology, Faculty of Mathematics and Natural Sciences, Universitas Terbuka. Jl. Cabe Raya Pondok Cabe, Pamulang, Tangerang Selatan, \\ Banten, Indonesia. Tel./fax.: +62-21-7490941, ‘email: ernik@ecampus.ut.ac.id \\ ${ }^{2}$ The Indonesian Tropical Institute (LATIN). Jl Sutera No 1, Situgede, Bogor 16115, West Java, Indonesia \\ ${ }^{3}$ The Indonesian Geospatial Information Agency. Jl. Raya Bogor Km 46, Nanggewer Mekar, Cibinong, Bogor 16911, West Java, Indonesia
}

Manuscript received: 9 January 2019. Revision accepted: 30 March 2019.

\begin{abstract}
Yuliana E, Hewindati YT, Winata A, Djatmiko WA, Rahadiati A. 2019. Diversity and characteristics of mangrove vegetation in Pulau Rimau Protection Forest, Banyuasin District, South Sumatra, Indonesia. Biodiversitas 20: 1215-1221. The purpose of the study was to analyze the flora diversity and characteristics of mangrove vegetation in Pulau Rimau Protection Forest, Banyuasin District, South Sumatra. Data collected were the number and girth diameter of mangrove tree species, and aquatic ecology parameters using transect method. The sample plots size were $2 \mathrm{~m} \times 2 \mathrm{~m} ; 5 \mathrm{~m} \times 5 \mathrm{~m} ; 10 \mathrm{~m} \times 10 \mathrm{~m}$; for seedling, sapling, and tree, respectively. The observation plots were arranged in a row of $120 \mathrm{~m}$ length on two sides of the forest edge, namely Calik Riverbank and Banyuasin Riverbank. Data were analyzed using importance value index (IVI), Simpson's diversity index and Sørensen's community similarity. The study revealed that there were differences in mangrove characteristics in two study sites. There were 57 plant species identified inside and outside sample plots, but only 15 species $(26.32 \%)$ among them were categorized as true mangrove species. Inside the sample plots, there were 11 and 10 mangrove tree species recorded on the Calik Riverbank and Banyuasin Riverbank, respectively, but only 7 species among them were found in both sites. The mangroves on Calik Riverbank were dominated by Nypa (IVI 53.59\%) and Bruguiera (51.12\%), while those on Banyuasin Riverbank were dominated by Sonneratia (66.91\%) and Avicennia (51.73\%). The Simpson's diversity index for Calik Riverbank and Banyuasin Riverbank was 0.82 and 0.78 , respectively, whereas the Sørensen's coefficient of community between the two sites was 0.67 .
\end{abstract}

Keywords: Coefficient of community, diversity, diversity index, mangrove

\section{INTRODUCTION}

The mangrove ecosystem is one of the important ecosystems in coastal and marine areas, functioning as the habitat for various types of organisms. The mangrove ecosystem is a unique ecosystem, known as a trap for mud and debris carried by the ocean currents, including organic waste and other waste materials from land. The mangrove substrate is famous for its fertility, functioning as a habitat for various types of biotas (Winata and Rusdiyanto 2015). In coastal areas, this ecosystem mainly forms a green strip along the coast/estuary and is very important for fish hatchlings/fish and prawns as well as to maintain the quality of the fishery and ecosystem, and agriculture (Indrayanti et al. 2015).

Another ecological role played by the mangrove ecosystem is as a barrier to protect the adjacent areas from the destructive energy of waves. Mangroves can reduce the effect of storm waves and protect the area of beaches that are affected by storms, and had been observed to even weaken the tsunami wave in India in 2004 (Das 2013). Another benefit is that the mangrove ecosystem is also useful for the people around it for fulfilling some of their daily needs, for example utilizing mangrove wood (especially Rhizophora, Bruguiera and Ceriops) for building materials, harvesting shellfish, snails, crustaceans, and fish as a source of protein, and collecting ingredients for traditional medicine (Winata and Rusdiyanto 2015).

Because the mangrove plays various roles and has many benefits for the environment and the people, mangrove ecosystem must be preserved so that it may continue to provide ecosystem services for the benefit of humankind (Winata et al. 2017). Mangroves on northern Rimau Island have been declared as a coastal protection forest based on their location on the inside of the Banyuasin River estuary, on the east coast of Sumatra Island; namely Pulau Rimau Protection Forest (KPHL Unit I Banyuasin 2017). Besides functioning as protected forest, these mangroves also provide direct utilization functions for the surrounding community, for example as a source of firewood, nipa palm leaves as roofing material, fish, crabs, et cetera. To understand the importance of the mangrove area of the Pulau Rimau Protection Forest, there is a need for collection of the area's basic data, one of which is the vegetation diversity and the related mangrove vegetation characteristics.

The purpose of this study was to analyze the floral diversity and the characteristics of mangrove vegetation in the Pulau Rimau Protection Forest. The vegetation characteristics include the species composition and vegetation structure of the mangrove stands and the condition of the related substrate. 


\section{MATERIALS AND METHODS}

\section{Study area}

The study area was the Pulau Rimau Protection Forest, in the Pulau Rimau Sub-district and Kuala Puntian Village, Tanjung Lago Sub-district, Banyuasin District, South Sumatra, Indonesia. Figure 1 showed the land cover map of Pulau Rimau and Tanjung Lago Sub-districts, where mangrove ecosystems are located along the coast.

\section{Procedures}

\section{Object of study}

The object of the study was the mangrove forest stands in the Pulau Rimau Protection Forest. The area studied were the mangrove forest areas which were often exploited by the community, both directly and indirectly, and were relatively close to settlements. Two sides of the Pulau Rimau Protected Forest, the west side on the banks of Calik River and the east side on the banks of Banyuasin River, were selected as study sites.

Vegetation data were collected through systematic sampling (Krebs 1989; Walpole 1995) by creating two transect paths which were placed approximately perpendicular to the banks of the larger rivers, e.g., Calik River (Penuguan River) and Banyuasin River, draw from the river banks to the forest interior. The two large rivers have widths of more than $1 \mathrm{~km}$ at the transect starting points.

\section{Data collection}

The data collected during this study were primary and secondary data. The primary data were the species composition, vegetation structure (tree density, basal area, and mangrove regeneration), and related substrate conditions (types of substrate, $\mathrm{pH}$, river water turbidity and temperature). Secondary data included various supporting information which was required in the discussion and conclusion, including the interaction between local community and the mangrove forest.

The definition of regeneration level used in this study was: 1) Seedlings are regenerated from sprouts to young plants up to $1.5 \mathrm{~m}$ high; 2) Saplings are young trees from $1.5 \mathrm{~m}$ high to treelets with a DBH (diameter at breast height) of less than $10 \mathrm{~cm}$; 3) Trees are stands with a DBH of $10 \mathrm{~cm}$ or more (Cintron and Novelli 1984; Soerianegara and Indrawan 1987).

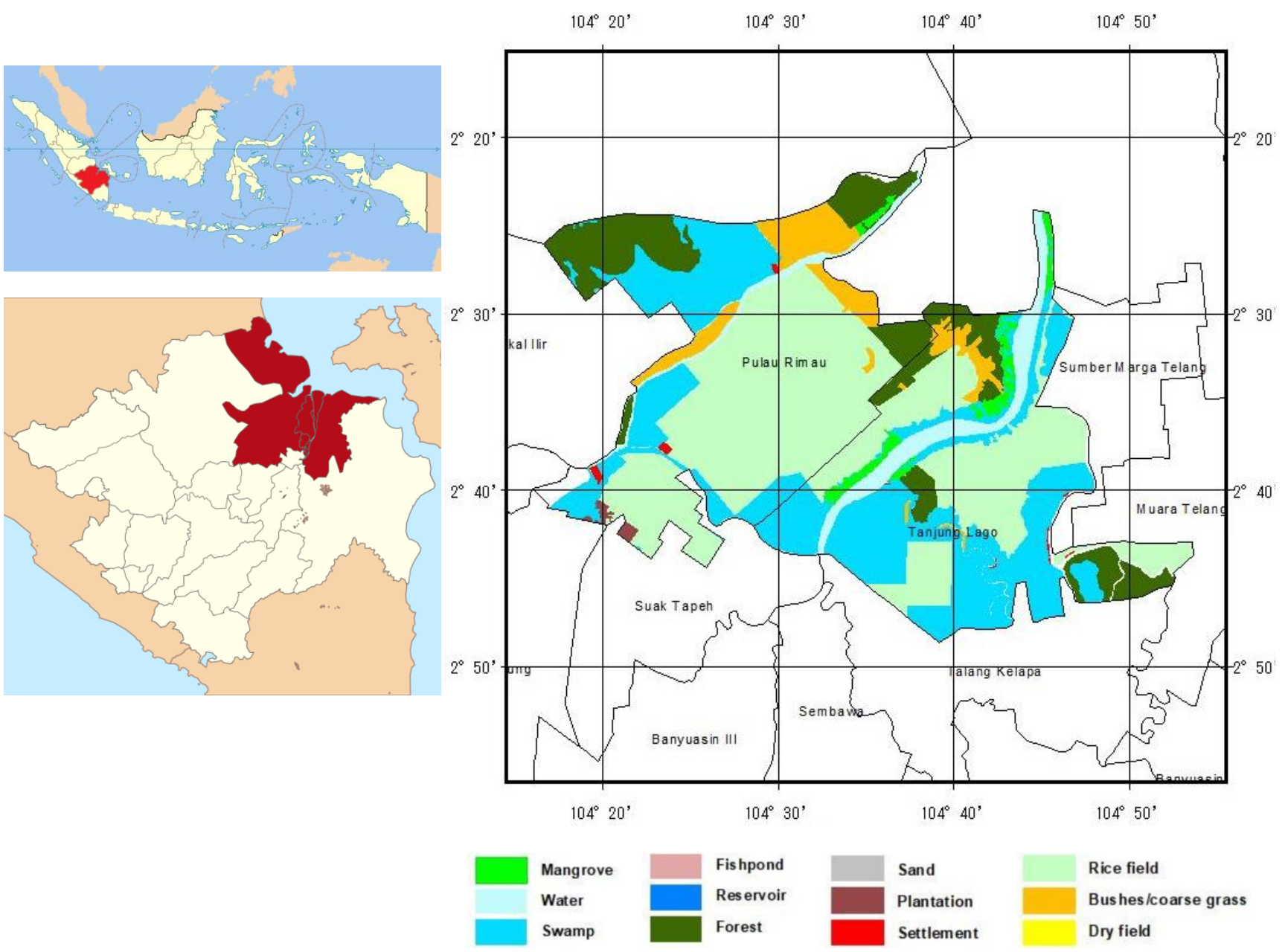

Figure 1. Land cover map of Pulau Rimau and Tanjung Lago Sub-districts, Banyuasin District, South Sumatra, Indonesia 
Two study sites were chosen in the two sides of Pulau Rimau Protection Forest, namely the Calik Riverbank at the northwest side and the Banyuasin Riverbank at the southeast side of the forest. In each area, a transect line consisting of 12 plots was drawn; totaling 24 plots for both sides. Data were collected through a vegetation analysis technique using transect method (Soerianegara and Indrawan 1987; Bengen 2002). Sample plots were made in squares of varying sizes, e.g., $2 \mathrm{~m} \mathrm{x} 2 \mathrm{~m}$ for seedlings; $5 \mathrm{~m}$ x $5 \mathrm{~m}$ for saplings; and $10 \mathrm{~m} \times 10 \mathrm{~m}$ for trees. In the field, the three sizes of sample plots were arranged as drawn in Figure 2.

\section{Data analysis}

Flora diversity was analyzed descriptively by presenting the numbers and groupings of plant species. Vegetation structure was examined by calculating the Importance Value Index (IVI) which consists of relative species density, and relative species frequency. The Simpson's Diversity Index (1-D) and Sørensen's community similarity coefficient were calculated according to the formula in Krebs (1989).

\section{RESULTS AND DISCUSSION}

\section{Mangrove floral composition}

At least, there were 57 species of plants recorded inside and outside the sample plots; 24 among them were tree species and the remaining were shrubs and herbs. Out of 57 species, 15 species (26.32\%) were known as true mangrove species and 18 species (31.58\%) were categorized as associate mangrove species. The rest of them further categorized as 12 species $(21.05 \%)$ of plants commonly found in swamps and 12 species $(21.05 \%)$ of secondary terrestrial vegetation plants (Figure 3 ).

All of plant species found and their grouping (Table 1) is showing the diversity of mangrove flora in study sites. True mangrove, according to Tomlinson (1986), were mangrove species that have been possessing morphological specialization and physiological mechanisms that adapt them to their environment, occurring only in the mangrove environment and not extending into terrestrial communities. True mangroves are found exclusively in the mangrove habitat (Giesen and Wulfraat 2006; FAO 2007). Associate mangroves are often found in mangrove environment, but not exclusively as they could be found also outside mangroves (Tomlinson 1986; Noor et al. 1999; Giesen and Wulfraat 2006).

Species that are marked with an $s$ in Table 1 showed that these species were typical flora of secondary vegetation, and most of them were pioneer species which readily invade open areas of forests. Species from the genera of Macaranga and Mallotus, together with Commersonia, Trema, and Trichospermum, are classified as short-lived pioneer trees (Whitmore 1984); species that grow quickly but also die or disappear quickly from the secondary vegetation community. Paperbark tree (Melaleuca) are often found dominating secondary forests that had burned, especially in peatland marsh areas (Anwar et al. 1984, Whitmore 1984, MacKinnon et al. 1996).

Secondary vegetation flora consisted also with shrubs and ground-dwelling herbs. Some herbaceous species such as Cayratia and Cissus vines, and Mimosa were adapted to dryland. Other herbaceous species that commonly found in disturbed mangroves were mangrove fern (Acrostichum), sea holly (Acanthus), sea derris (Derris trifoliata) and, in watery areas, Cyperus malaccensis (Phan and Hoang 1993).

\section{Mangrove vegetation structure}

There were 183 tree individuals from 14 mangrove species found inside the sampling plots. The species that comprise the mangrove forest studied were Avicennia alba, A. officinalis, Barringtonia conoidea, Bruguiera gymnorrhiza, B. sexangula, Ceriops tagal, Excoecaria agallocha, Heritiera littoralis, Nypa fruticans, Pongamia pinnata, Rhizophora stylosa, R. mucronata, Sonneratia caseolaris, and Xylocarpus granatum.

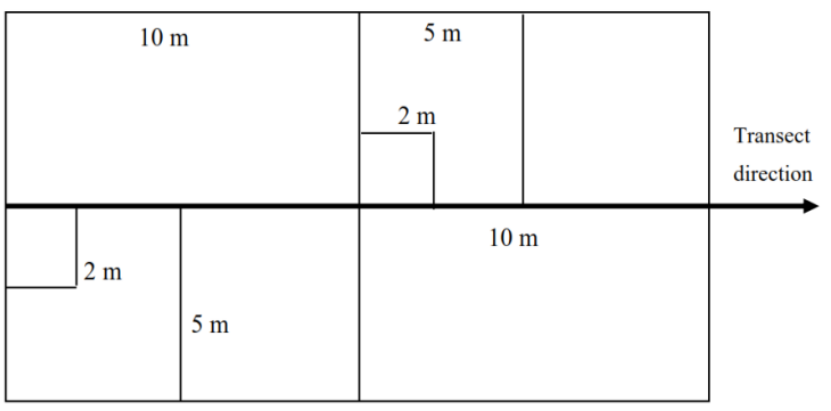

Figure 2. Placement of measurement plots according to the transect method

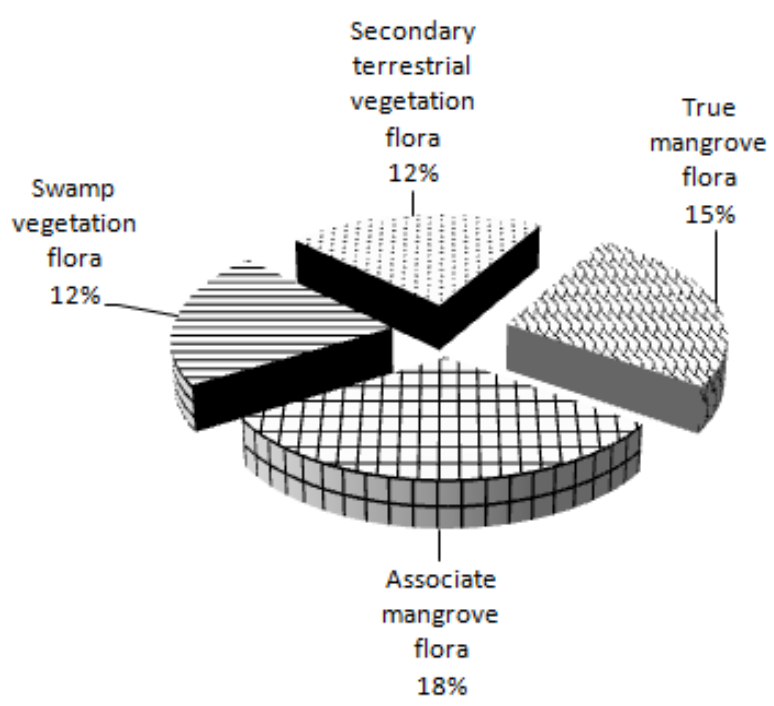

Figure 3. The floral composition of mangrove stands in the Pulau Rimau Protection Forest, Banyuasin, Indonesia 
Table 1. A list of plant species found in the study area and their groupings

\begin{tabular}{|c|c|c|c|c|c|}
\hline Family and scientific name & Local name & $\mathbf{M}$ & $\mathbf{A}$ & $\mathbf{R}$ & $\mathbf{S}$ \\
\hline Acanthus ilicifolius & Jeruju & $\mathrm{m}$ & & & \\
\hline Acrostichum aureum & Paku laut & $\mathrm{m}$ & & & \\
\hline Allophylus cobbe & Penancang & & $\mathrm{a}$ & & \\
\hline Alstonia spathulata & Pulai rawa & & & $\mathrm{r}$ & \\
\hline Avicennia alba & Api-api putih & $\mathrm{m}$ & & & \\
\hline Avicennia officinalis & Api-api ludat & $\mathrm{m}$ & & & \\
\hline Barringtonia conoidea & Putat sungai & & $\mathrm{a}$ & & \\
\hline Bruguiera gymnorrhiza & Tumu & $\mathrm{m}$ & & & \\
\hline Bruguiera sexangula & Pertut & $\mathrm{m}$ & & & \\
\hline Caesalpinia sp. & - & & $\mathrm{a}$ & & \\
\hline Cayratia trifolia & Galing-galing & & & & $\mathrm{s}$ \\
\hline Cerbera manghas & Bintaro & & a & & \\
\hline Ceriops tagal & Tengar & $\mathrm{m}$ & & & \\
\hline Cissus hastata & Akar asam riang & & & & $\mathrm{s}$ \\
\hline Citrus sp. & Limau & & a & & \\
\hline Commelina nudiflora & Gewor & & & $\mathrm{r}$ & \\
\hline Crinum asiaticum & Bakung & & & $\mathrm{r}$ & \\
\hline Cyperus javanica & Rumput lingsing & & & $\mathrm{r}$ & \\
\hline Cyperus malaccensis & Wlingi laut & & a & & \\
\hline Derris trifoliata & Tuba laut & & $\mathrm{a}$ & & \\
\hline Eclipta alba & Urang-aring & & & $\mathrm{r}$ & \\
\hline Eleocharis dulcis & Tike & & $\mathrm{a}$ & & \\
\hline Excoecaria agallocha & Buta-buta & $\mathrm{m}$ & & & \\
\hline Ficus benjamina & Beringin & & & & $\mathrm{s}$ \\
\hline Ficus sp & Ara & & & $\mathrm{r}$ & \\
\hline Ficus sp.2 & Ara rambat & & & & $\mathrm{s}$ \\
\hline Fimbristylis sericea & - & & & $\mathrm{r}$ & \\
\hline Flagellaria indica & Rotan tikus & & $\mathrm{a}$ & & \\
\hline Glochidion littorale & Dempul & & $\mathrm{a}$ & & \\
\hline Heritiera littoralis & Dungun & $\mathrm{m}$ & & & \\
\hline Hibiscus tiliaceus & Waru & & $\mathrm{a}$ & & \\
\hline Imperata cylindrica & Ilalang & & & & $\mathrm{s}$ \\
\hline Leptochloa cf neesii & Perumpungan & & & & $\mathrm{s}$ \\
\hline Ludwigia octovalvis & Lombokan & & & $\mathrm{r}$ & \\
\hline Lygodium flexuosum & Paku hata & & & & $\mathrm{s}$ \\
\hline Macaranga cf hypoleuca & Mahang putih & & & $\mathrm{r}$ & \\
\hline Mallotus paniculatus & Balik angin & & & & $\mathrm{s}$ \\
\hline Melaleuca cajuputi & Gelam & & & $\mathrm{r}$ & \\
\hline Melastoma malabathricum & Senggani & & $\mathrm{a}$ & & \\
\hline Mimosa pigra & Sikejut besar & & & $\mathrm{r}$ & \\
\hline Mimosa pudica & Sikejut & & & & $\mathrm{s}$ \\
\hline Nypa fruticans & Nipah & $\mathrm{m}$ & & & \\
\hline Paspalum vaginatum & Rumput pahit & & & & $\mathrm{s}$ \\
\hline Phragmites karka & Perumpung & & & $\mathrm{r}$ & \\
\hline Pluchea indica & Beluntas & & a & & \\
\hline Pongamia pinnata & Malapari & & $\mathrm{a}$ & & \\
\hline Rhizophora apiculata & Bakau minyak & $\mathrm{m}$ & & & \\
\hline Rhizophora mucronata & Bakau kurap & $\mathrm{m}$ & & & \\
\hline Scirpus cf littoralis & Endong & & a & & \\
\hline Sonneratia caseolaris & Pedada & $\mathrm{m}$ & & & \\
\hline Sphaeranthus indicus & Mundika & & & & $\mathrm{s}$ \\
\hline Stenochlaena palustris & Paku udang & & $\mathrm{a}$ & & \\
\hline Sarcolobus globosus & Akar batu & $\mathrm{m}$ & & & \\
\hline Terminalia catappa & Ketapang & & a & & \\
\hline Uncaria sp. & Akar kekait & & & & $\mathrm{s}$ \\
\hline Wedelia biflora & Seruni & & $\mathrm{a}$ & & \\
\hline Xylocarpus granatum & Nyirih & $\mathrm{m}$ & & & \\
\hline
\end{tabular}

Note: $\mathrm{m}=$ true mangrove flora, $\mathrm{a}=$ associate mangrove flora, $\mathrm{r}=$ swamp vegetation flora, $\mathrm{s}=$ secondary terresterial vegetation flora
According to stands composition, the mangrove forest on the Calik Riverbank was dominated by nipa palm (Nypa fruticans), accounting for approximately $30.86 \%$ of the number of trees recorded in the plot, followed by pertut (Bruguiera sexangula) $28.40 \%$ and kayu buta-buta (Excoecaria agallocha, blind-your-eye) $14.81 \%$ (Table 2). Meanwhile, the mangrove on the Banyuasin Riverbank was dominated by pedada (Sonneratia caseolaris, mangrove apple), consisting of $48.39 \%$ of the number of trees recorded in the plot. A large number of pedada individuals was because most of these trees were young, comprising the succession layers of the mangrove forest on the newly formed mud plains on the banks of Banyuasin River. The first plot on the river bank was even filled solely with $S$. caseolaris individuals at seedling and sapling stages. The next dominant species was api-api ludat (Avicennia officinalis) at $25.81 \%$, and nipa palm at $12.90 \%$ (Table 2 and Figure 5).

The difference between the two mangrove forest stands was further supported by the results of the vegetation analysis which revealed that Nypa fruticans, Bruguiera sexangula, and Excoecaria agallocha were the top three in the Importance Value Index (IVI) of mangrove trees on the Calik Riverbank, with IVIs of $53.59 \%, 51.12 \%$, and $33.00 \%$, respectively. On the other hand, the mangrove trees with the top three IVI on the Banyuasin Riverbank were Sonneratia caseolaris (66.91\%), Avicennia officinalis $(51.73 \%)$, and then Nypa fruticans $(31.42 \%)$ (Table 2, Figure 4 and Figure 5).

\section{Diversity of fauna}

There were at least 82 species of fauna found in the mangrove forest studied and the surrounding areas, consisting of 6 mammalian species, 56 avian species, 8 herpetofauna species (reptiles and amphibians), 8 fish species, and 4 crustacean species. A large number of bird species observed was associated with the ease of which they were observed, either when flying or not. The other groups of animals were more secretive or hidden in their habitats (bushes, burrows, or underwater). Among them, there were several species considered as important according to IUCN (The World Conservation Union), CITES (The Convention on International Trade of Endangered Species fo Flora and Fauna), or protected by Indonesian Law (Table 3).

Table 2. Three tree species with the highest Importance Value Index (IVI) in the two study locations

\begin{tabular}{|c|c|c|c|c|c|c|}
\hline Species & $\sum_{\text {indiv. }}$ & $\begin{array}{l}\text { RD } \\
(\%)\end{array}$ & $\mathbf{F}$ & $\begin{array}{l}\text { RF } \\
(\%)\end{array}$ & $\begin{array}{l}\text { IVI } \\
(\%)\end{array}$ & $1-D$ \\
\hline \multicolumn{7}{|c|}{ Calik River Mangroves } \\
\hline Nypa fruticans & 25 & 30.86 & 0.83 & 22.73 & 53.59 & 0.82 \\
\hline Bruguiera sexangula & 23 & 28.40 & 0.83 & 22.73 & 51.12 & \\
\hline $\begin{array}{l}\text { Excoecaria } \\
\text { agallocha }\end{array}$ & 12 & 14.81 & 0.67 & 18.18 & 33.00 & \\
\hline \multicolumn{7}{|c|}{ Banyuasin River Mangroves } \\
\hline Sonneratia caseolaris & 45 & 48.39 & 0.42 & 18.52 & 66.91 & 0.78 \\
\hline Avicennia officinalis & 24 & 25.81 & 0.58 & 25.93 & 51.73 & \\
\hline Nypa fruticans & 12 & 12.90 & 0.42 & 18.52 & 31.42 & \\
\hline
\end{tabular}

Note: $\mathrm{RD}=$ relative density; $\mathrm{F}=$ frequency; $\mathrm{RF}=$ relative frequency; IVI = important value index; 1 - D = Simpson's index 


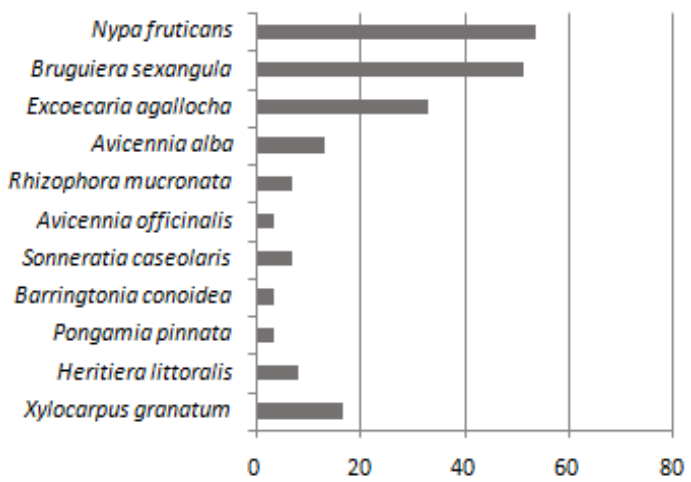

Figure 4. Importance Value Indices for the trees in the Calik Riverbank site

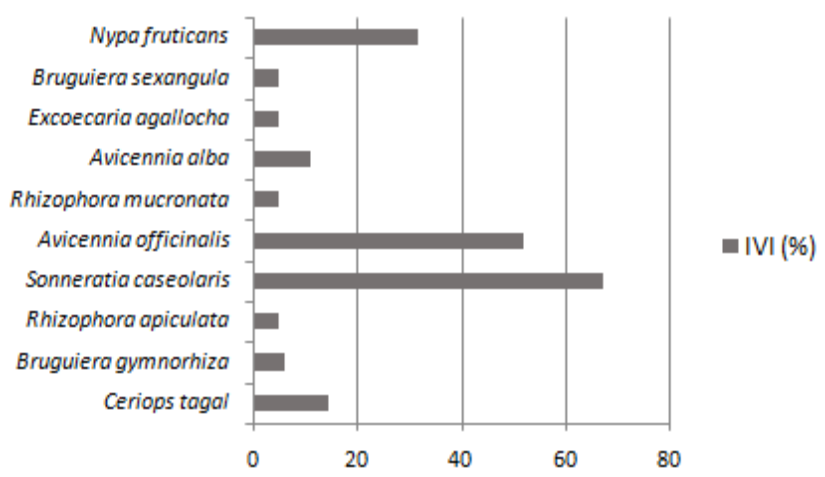

Figure 5. Importance Value Indices for the trees in the Banyuasin Riverbank site

Table 3. Important species of fauna recorded at the study sites and the surrounding areas

\begin{tabular}{|c|c|c|c|c|c|}
\hline Scientific name & Local name & English name & IUCN & CITES & RI Law \\
\hline Aethopyga siparaja & Burung-madu sepah-raja & Crimson sunbird & LC & - & $\mathrm{L}$ \\
\hline Anthreptes malacensis & Burung-madu kelapa & Plain-throated sunbird & $\mathrm{LC}$ & - & $\mathrm{L}$ \\
\hline Cinnyris jugularis & Burung-madu sriganti & Olive-backed sunbird & $\mathrm{LC}$ & - & $\mathrm{L}$ \\
\hline Crocodylus porosus & Buaya muara & Salt-water crocodile & $\mathrm{LC}$ & App II & $\mathrm{L}$ \\
\hline Halcyon smyrnensis & Cekakak belukar & White-throated kingfisher & $\mathrm{LC}$ & - & $\mathrm{L}$ \\
\hline Haliaeetus leucogaster & Elang laut & White-bellied sea eagle & $\mathrm{LC}$ & App II & $\mathrm{L}$ \\
\hline Haliastur indus & Elang bondol & Brahminy kite & $\mathrm{LC}$ & App II & $\mathrm{L}$ \\
\hline Ictinaetus malaiensis & Elang hitam & Black eagle & $\mathrm{LC}$ & App II & $\mathrm{L}$ \\
\hline Leptocoma calcostetha & Burung-madu bakau & Copper-throated sunbird & $\mathrm{LC}$ & - & $\mathrm{L}$ \\
\hline Leptoptilos javanicus & Bangau tongtong & Lesser adjutant & VU & - & $\mathrm{L}$ \\
\hline Macaca fascicularis & Monyet kra & Crab-eating monkey & $\mathrm{LC}$ & App II & - \\
\hline Malayopython reticulatus & Ular sanca kembang & Reticulated python & $\mathrm{NE}$ & App II & - \\
\hline Mycteria cinerea & Bangau bluwok & Milky stork & $\mathrm{EN}$ & App I & $\mathrm{L}$ \\
\hline Pelargopsis capensis & Pekaka emas & Stork-billed kingfisher & $\mathrm{LC}$ & - & $\mathrm{L}$ \\
\hline Prionailurus bengalensis & Macan akar & Leopard cat & $\mathrm{LC}$ & App II & $\mathrm{L}$ \\
\hline Ptyas cf. mucosus & Ular tikus besar & Greater rat-snake & - & App II & - \\
\hline Rhipidura javanica & Kipasan belang & Pied fantail & $\mathrm{LC}$ & - & $\mathrm{L}$ \\
\hline Spilornis cheela & Elang ular bido & Crested serpent-eagle & $\mathrm{LC}$ & App II & $\mathrm{L}$ \\
\hline Todiramphus chloris & Cekakak sungai & Collared kingfisher & $\mathrm{LC}$ & - & $\mathrm{L}$ \\
\hline Trachypithecus cristatus & Lutung cingku & Silvered leaf-monkey & NT & App II & - \\
\hline Varanus salvator & Biawak air & Common monitor & $\mathrm{LC}$ & App II & - \\
\hline
\end{tabular}

Notes: IUCN status: EN, Endangered; LC, Least Concern; NE, Not Evaluated; NT, Near Threatened; VU, Vulnerable; CITES: App I, listed in Appendix I; App II, Appendix II; RI Law: L, protected by the law (RI Government Regulation no 7/1999)

\section{Discussion}

The proportion of true mangrove species in the area studied was only one fourth of the total existing species (Figure 3), whereas the true mangrove species are the main component of the mangrove ecosystem which is the indicator of the condition of the mangrove forest itself (FAO 2007; WOA RPROC 2016). Tomlinson (1986) defined true mangrove species as mangrove species that have adapted well with high-salinity environments through both morphological and physiological adaptation mechanisms, so they only thrive in the mangrove ecosystem and play an important role in creating its community structure. True mangroves are naturally only found in the mangrove ecosystem (Giesen and Wulfraat 2006). Associate mangroves are plant species that are found living in the mangrove ecosystem but are able to live in other ecosystems (Noor et al. 1999). In Southeast Asia, Giesen and Wulfraat (2006) have listed 52 species of true mangroves and 216 species of associate mangroves, while in Indonesia the numbers are 43 species of true mangroves and 159 species of associate mangroves (Noor et al. 1999).

The high proportion of non-true mangroves, the associate mangrove group and non-mangroves (totaling $73.68 \%$ ), recorded on the location suggested that the Rimau Island coastal protection forest was categorized as a disturbed ecosystem. Changes in the floristic composition of a mangrove forest could be due to natural changes in the environment or due to human actions or disruptions, or due to a combination of the two (Saenger 2002). 
Referring to the composition of mangrove individuals that were recorded (Table 2, Figure 4 and 5), there was a clear difference between the mangrove forest stands on the Calik Riverbank and the Banyuasin Riverbank. Simpson's Diversity Index (1-D) for the two locations were 0.82 (Calik Riverbank) and 0.78 (Banyuasin Riverbank) (Table 2 ). The diversity index represents the chances of the next species being observed is differing from the previous one; therefore, a value of 0 means that the community is uniform or homogeneous and a value approaching 1 means that the community is highly diverse (Krebs 1989). The Simpson's Diversity Index found was fairly high; suggesting that the two locations studied had a rather high diverse vegetation.

From the mangrove tree species diversity point of view, the two mangrove stands were almost the same, having 11 species of trees recorded in the Calik Riverbank and 10 species of trees in the Banyuasin Riverbank; totaling 14 species. However, out of the 14 species, only 7 species were recorded in the sample plots of the two sides of the Pulau Rimau Protection Forest. Another 4 species were recorded only on the Calik Riverbank and the last 3 species were only observed on the Banyuasin Riverbank. Nevertheless, the Sørensen's coefficient of community was 0.67 . This value suggests that the similarity between the two mangrove communities was relatively high. Theoretically, the Sørensen's coefficient of community ranges between 0.0 (or $0 \%$, which means the two sample communities compared are not similar at all) and 1.0 (or $100 \%$, which means the two samples are identical) (Krebs 1989; Mueller-Dombois and Ellenberg 2003). Index value greater than $65 \%$ suggests a fairly high floristic similarity (Prawiroatmodjo and Kartawinata 2014, Srivastava and Shukla 2016).

The difference in mangrove tree species, especially the dominating species, is believed to be associated with the substrate conditions that are different on the two sides of the Pulau Rimau Protection Forest. As mentioned above, the forest on the Banyuasin Riverbank is situated where new mud is deposited, leading to the domination of Sonneratia caseolaris and Avicennia officinalis in the succession of mangrove vegetation. On the other hand, the forest on the banks of Calik River is located on a substrate that is more settled and solid. This part is a transition between the mangrove forest dominated by Bruguiera sexangula and Excoecaria agallocha and the mangrove area was dominated by Nypa fruticans.

Avicennia and Sonneratia often dominated the foremost area of mangrove forests, or the area closest to the sea, with substrate in the form of soft mud with high organic matter content (Watson 1928; Sukarjo and Kartawinata 1979). This area is often referred to as the Zone 1 of mangroves, which is the outermost zone where new mud is deposited. In addition to these two genera (Avicennia and Sonneratia), Rhizophora -especially $R$. mucronata- as mentioned by Steenis (1958), is known to prefer conditions where the substrate is deep soft mud.

The Bruguiera genus usually grows in the zone more inland, with a more settled substrate, more solid, and is only flooded by monthly tides. Even in the Calik Riverbank site, where $B$. sexangula dominated the stand, the species is only found inland, although not far from the edge of water. $B$. cylindrica, B. parviflora and B. sexangula also grow in areas not far from rivers, but on higher ground only inundated by tides once in a while (Watson, 1928; Steenis, 1958, Saenger 2002).

The nipa palm (Nypa fruticans) in the study sites were observed growing in a narrow strip along the banks of Calik River or forming a wide band behind the area populated by many mangrove trees. Nipa palms mainly grow in the interior of mangroves at the high tide mark, often forming pure stands alongside the river (Whitmore 1984; Gee 2001). However, the nipa palm is not very sensitive to changes in water salinity and is able to grow well at salinity level range of $1-30 \%$. The nipa palm is also known to favor places with strong water currents such as river banks (Steenis 1958). More inland, nipa palm might be associated with places with many mud lobster (Thalassina anomala) nesting mounds (Whitmore 1984).

Mangrove stand on the sides of Banyuasin River was dominated by $S$. caseolaris, particularly in the riverbank. Sonneratia caseolaris and Nypa fruticans are often dominant in areas with brackish water, especially along the riverside which has brackish to nearly-fresh water as the mangrove at the back of estuaries (Phan and Hoang 1993, Noor et al. 1999). Such situation agreed with the study sites that located far behind the Banyuasin River estuary, but could still be reached by the tidal waters.

From the conservation point of view, there were 16 species among recorded fauna in the study sites that protected under the Republic of Indonesia's law, consisting of 1 mammalian species, 14 avian species, and 1 reptilian species. One of the bird species, the milky stork (Mycteria cinerea), was declared as Endangered (IUCN 2017). This species was also listed in Appendix I CITES which means that the trade of this species is banned internationally (CITES 2017). Another stork species, the lesser adjutant (Leptoptilos javanicus), had its population declared as Vulnerable (IUCN 2017), while the silvered langur (Trachypithecus cristatus) was listed as Near Threatened (IUCN 2017). Meanwhile, there were another 11 species listed in Appendix II CITES, which means trade is controlled with a limited quota (CITES 2017). The high proportion of important species of fauna in the study sites (Table 3), e.g. 21 out of 82 species $(25.61 \%$ ), shows that the Pulau Rimau protection forest still has a significant role as habitat of wild fauna.

\section{ACKNOWLEDGEMENTS}

The authors are grateful to the Universitas Terbuka for providing the research funding through the fundamental research scheme. We also thanks to the local government of Pulau Rimau for granting permission to conduct research in the study site. And finally, we would like to thank anonymous reviewer for valuable comments and criticism that helped substantially to improve the manuscript. 


\section{REFERENCES}

Anwar J, Damanik SJ, Hisyam N, Whitten AJ. 1984. The ecology of Sumatran ecosystems. Gadjah Mada Univ. Press, Yogyakarta. [Indonesian].

Bengen DG. 2002. Technical guidance for identification and management of mangrove forest. Pusat Kajian Sumberdaya Pesisir dan Lautan IPB, Bogor. [Indonesian]

Cintron G, Novelli YS. 1984. Methods for studying mangrove structure In: Snedaker SC, Snedaker JG. (eds.) The Mangrove Ecosystem: research methods. UNESCO, Paris.

CITES. 2017. Appendices I, II and III valid from 04 October 2017. UNEP Geneva,

Switzerland. http://www.cites.org/eng/app/appendices.php

Das S, Crepin AS. 2013. Mangroves can provide protection against wind damage during storms. Estuarine, Coastal and Shelf Science 134 (2013): 98-107.

Ding Hou. 1958. Rhizophoraceae. Flora Malesiana ser. I, no. 5: 429-93.

FAO. 2007. The world's mangrove 1980-2005. FAO Forestry Paper no 153. Food and Agriculture Organization, Rome.

Gee CT. 2001. The mangrove palm Nypa in the geologic past of the New World. Wetlands Ecol Manag 9: 181-94.

Indrayanti MD, Fahrudin A, Setiobudiandi I. 2015. Ecosystem service assessment in Blanakan Bay, Subang District. Jurnal Ilmu Pertanian Indonesia 20 (2): 91-96. [Indonesian]

IUCN. 2017. IUCN Red List of Threatened Species. Version 2017-2. www.iucnredlist.org

Krebs CJ. 1989. Ecological Methodology. Harper \& Row, New York.

KPHL Unit I Banyuasin. 2017. About us. https://kphlbanyuasin.wordpress.com/about/ [Indonesian].

MacKinnon K, Hatta G, Halim H, Mangalik A. 1996. The Ecology of Kalimantan. Periplus Editions, Hong Kong.

Mueller-Dombois D, Ellenberg H. 2003. Aims and Methods of Vegetation Ecology. Blackburn Press, Caldwell, NJ.

Noor YR, Khazali M, Suryadiputra INN. 1999. Identification Guide for Mangrove in Indonesia. Ditjen PKA \& Wetlands International Indonesia Programme, Bogor. [Indonesian].

Phan NH, Hoang TS. 1993. Mangroves of Vietnam. IUCN, Bangkok.
Prawiroatmodjo S, Kartawinata K. 2014. Floristic diversity and structural characteristics of mangrove forest of Raja Ampat, West Papua, Indonesia. Reinwardtia 14 (1): 171-80.

Saenger P. 2002. Mangrove Ecology, Silviculture and Conservation. Kluwer Academic, Dordrecht.

Soerianegara I, Indrawan A. 1987. Indonesian Forest Ecology. Faculty of Forestry Bogor Agricultural University, Bogor. [Indonesian].

Srivastava S, Shukla RP. 2016. Similarity and difference of species among various plant communities across grassland vegetation of northeastern Uttar Pradesh. Trop Plants Res 3 (2): 364-369.

Steenis CGGJ van. 1958. Introductory matter on ecology. In: Ding Hou. Rhizophoraceae. Flora Malesiana ser. I, 5: 431-436.

Sukarjo S, Kartawinata K. 1979. Mangrove forest of Banyuasin, Musi River Estuary, South Sumatra. In: Srivastava et al. (eds) Mangrove and estuarine vegetation in Southeast Asia. Biotrop Special Publication 10: 61-79.

Tomlinson PB. 1986. The Botany of Mangroves. Cambridge Univ. Press, Cambridge.

Walpole RE. 1995. Introduction to Statistics. $3^{\text {rd }}$ Ed transl. Gramedia, Jakarta. [Indonesian].

Watson JG. 1928. The mangrove swamps of the Malay Peninsula. Malayan Forestry Record No. 6. Forest Research Institute Malaysia, Kepong, Kuala Lumpur.

Winata A, Rusdiyanto E. 2015. Mangrove vegetation diversity and substrate influence on their natural regeneration in Kemujan Island, Karimunjawa National Park. [Research Report]. Universitas Terbuka, Tangerang Selatan. [Indonesian].

Winata A, Yuliana E, Rusdiyanto E. 2017. Diversity and natural regeneration of mangrove vegetation in the tracking area on Kemujan Island Karimunjawa National Park, Indonesia. AES Bioflux 9 (2): 109-119.

Whitmore TC. 1984. Tropical Rain Forest of the Far East. Oxford, Kuala Lumpur.

WOA RPROC. 2016. The First Global Integrated Marine Assessment, World Ocean Assessment I. Report of the Group of Experts of the Regular Process. United Nations - World Ocean Assessment, New York 